\title{
Decrease in Ventilatory Capacity between Ages of 50 and 54 in Representative Sample of Swedish Men
}

\author{
LARS WILHELMSEN,* M.D.; IOAN ORHA, $\ddagger$ M.D. ; GÖSTA TIBBLIN, $\dagger$ M.D.
}

\begin{abstract}
Summary: The ventilatory capacity, including flow$S$ volume curves of 313 men, all 50 years old, was examined in 1963 and 1967. The group as a whole, which included persons with chronic bronchitis, with "other respiratory symptoms," and without respiratory symptoms, showed the same absolute decrease in ventilatory capacity.

Vital capacity, forced expiratory volume, and maximum expiratory flow all dropped more for the smokers than for either the non-smokers or the ex-smokers. In those who had stopped smoking for four years or less, however, ventilatory capacity did not decline significantly less than in those who continued to smoke.
\end{abstract}

\section{Introduction}

The effect of age, smoking, chronic bronchitis, and other circumstances on pulmonary ventilation has been studied repeatedly during the past 10 years. Nearly all the studies have been carried out on persons of different ages examined on one occasion only. Several studies of subjects of different ages with healthy lungs have shown by means of regression analysis that an approximately linear drop occurs in the ventilatory capacity with increasing age once the age of 20 has been passed (see Tables V and VI for references). Factors such as the nature of the ambient air and smoking habits also affect the ventilatory capacity. A better way of studying the influence of different factors is to follow pulmonary function from year to year in the same people (Higgins and Oldham, 1962 ; Fletcher, 1968 ; Higgins et al., 1968).

The present investigation had three aims: (1) to record the changes in the ventilatory capacity during a four-year period in a randomly selected sample of men born in the same year; (2) to determine whether there was any difference in the ventilatory capacity between groups which differed as regards respiratory symptoms and smoking habits; and (3) to analyse the drop with age in comparison with a prediction from regression equations.

The results of a cross-sectional study in 1963, using the same sample of men, on the connexion between smoking and ventilatory capacity have been published, as have the results from a control group without any respiratory symptoms (Wilhelmsen and Tibblin, 1966 ; Wilhelmsen, 1968).

\section{Material and Methods}

The population studied and the methods used have already been described (Wilhelmsen and Tibblin, 1966). All the subjects lived in Göteborg, a seaport in south-west Sweden. It is Sweden's second largest city, having 414,466 inhabitants

First Medical Service, Sahlgrenska Hospital, University of Göteborg, S-413 45 Göteborg, Sweden.

* Assistant Professor.

t Assistant Professor.

$¥$ Working on a grant from the Swedish National Association Against Heart and Chest Diseases. Present address: National Centre for Cardiovascular Disease (ASCAR), Bucharest, Rumania. in 1963, and is the centre of an industrial region containing shipyards and factories making machines, motor-cars, and ballbearings. The air in the centre of Göteborg is more polluted than that in the outskirts, but no subgroup of our population differed from the others as regards exposure to polluted air.

The names of all the men living in Göteborg born in 1913 on days of the month equally divisible by three were assembled. These totalled 973, and in 1963 extensive data on $88 \%$ of these were collected. We had intended to examine the ventilatory capacity of every second one of them, but could do so in only 339 subjects. So far as we knew this did not introduce any bias (Wilhelmsen and Tibblin, 1966). Four years later, in 1967, the same lung function tests on the 313 survivors of the 339 were performed. The results of this re-examination are given below.

Each of the 313 subjects underwent a thorough clinical study. We used the same definition for chronic bronchitis as the Medical Research Council's Committee on the Aetiology of Chronic Bronchitis (1965)-namely, cough and sputum in the morning and day or night for at least three months a year. Under "other respiratory symptoms" we included subjects having cough or sputum for less than three months a year, dyspnoea on climbing stairs or slight hills or walking quickly on flat ground, and wheezing. In the present paper we deal only with the observations on respiratory symptoms and ventilatory capacity.

The ventilatory capacity was tested by the same examiner and with the same spirometer in 1963 and 1967 . On both occasions the men were asked not to smoke for two hours before they were tested. In 1963 the tests were done between 9 and 10 a.m. and in 1967 between 3 and 4.30 p.m. On both occasions the subjects had fasted at least four hours before they were examined.

The respiratory volume and flow were measured with a Servo-Spirometer, model 150A (Med.-Science Electronics, Ohio, Mo., U.S.A.). This spirometer, electrically driven, presents little resistance to breathing. The frequency response amounted to $10 \mathrm{~Hz}$. The various apparatuses used in the examination procedure have been described in detail (Wilhelmsen, 1968).

The following properties were measured with the patient sitting: (1) vital capacity (V.C.), (2) forced expiratory volume in one second (F.E.V., ), (3) maximum expiratory flow when $50 \%$ of V.C. plus residual volume (R.V.) was left in the lungs (M.E.F. $50 \%$ ), and (4) maximum expiratory flow when $25 \%$ of V.C. plus R.V. was left in the lungs (M.E.F. $25 \%$ ). Numbers 3 and 4 were measured from flow-volume curves. The peak expiratory flow rate (P.E.F.) with the Wright peakflow meter according to the method recommended by Wright and McKerrow (1959), was determined with the subjects standing.

For the subsequent calculations we used the highest value obtained from three technically satisfactory measurements for the first four properties, and the average of the last three of five measurements for P.E.F. For statistical analysis of the changes occurring between 1963 and 1967 the differences between the two values were tested against the null hypothesis. We tested the difference in the changes in ventilatory capacity with Student's $t$ test. If the variances differed statistically we reduced the number of degrees of frecdom (Welch, 1949). 
Both the differences between the absolute changes in ventilatory capacity and between the relative changes (in percentage of the initial value for the variable in question) were tested.

\section{Results}

The findings are shown in Tables I-IV. All the groups showed about the same absolute decrease in values for the variables of ventilatory capacity on the second occasion (V.C., F.E.V., M.E.F. 50\%, and M.E.F. $25 \%$ ). The subjects with respiratory symptoms, who had lower values in 1963, showed a relatively larger reduction during the four years. No difference between the various groups in the lowering of ventilatory capacity was statistically significant (Table I).

During the four years the P.E.F. dropped relatively the same amount as the two other variables of flow (M.E.F. $50 \%$ and M.E.F. $25 \%$ ). The P.E.F. was measured by another examiner and with different apparatus from that used for the other two variables.

TABLE I.-Ventilatory Capacity (in litres) of Whole Series, Subjects with Chronic Bronchitis, Subjects with Other Respiratory Symptoms (Cough, Sputum, Dyspnoea, or Wheezing), and Subjects without Respiratory Symptoms. Means and Standard Deviations

\begin{tabular}{|c|c|c|c|c|c|}
\hline & & $\begin{array}{l}\text { 1. Whole } \\
\text { Series } \\
(n=313)\end{array}$ & $\begin{array}{c}\text { 2. Chronic } \\
\text { Bronchitis } \\
(n=19)\end{array}$ & $\begin{array}{l}\text { 3. With other } \\
\text { Respiratory } \\
\text { Symptoms } \\
(\mathbf{n}=114)\end{array}$ & $\begin{array}{l}\text { 4. Without } \\
\text { Respiratory } \\
\text { Symptoms } \\
(n=180)\end{array}$ \\
\hline $\begin{array}{l}\text { V.C. } \\
\text { (I.) }\end{array}$ & $\left\{\begin{array}{l}1963 \\
1967 \\
\text { Diff. }\end{array} \mid\right.$ & $\begin{array}{l}4.79 \pm 0.76 \\
4.47 \pm 0.76 \\
0.32 \pm 0.35\end{array}$ & $\begin{array}{l}4.71 \pm 0.69 \\
4.36 \pm 0.77 \\
0.35 \pm 0.23\end{array}$ & $\begin{array}{l}4.59 \pm 0.83 \\
4.30 \pm 0.82 \\
0.29 \pm 0.33\end{array}$ & $\begin{array}{l}4.93 \pm 0.71 \\
4.59 \pm 0.69 \\
0.33 \pm 0.35\end{array}$ \\
\hline $\begin{array}{l}\text { F.E.V.1 } \\
\text { (1.) }\end{array}$ & $\left\{\begin{array}{l}1963 \\
1967 \\
\text { Diff. }\end{array}\right.$ & $\begin{array}{l}3.62 \pm 0.60 \\
3.39 \pm 0.59 \\
0.23 \pm 0.33\end{array}$ & $\begin{array}{l}3.35 \pm 0.57 \\
3.13 \pm 0.63 \\
0.22 \pm 0.40\end{array}$ & $\begin{array}{l}3.43 \pm 0.60 \\
3.22 \pm 0.59 \\
0.21 \pm 0.30\end{array}$ & $\begin{array}{l}3.77 \pm 0.58 \\
3.53 \pm 0.56 \\
0.23 \pm 0.32\end{array}$ \\
\hline $\begin{array}{l}\text { P.E.F. } \\
\text { (i./min.) }\end{array}$ & $\begin{array}{r}1963 \\
1967 \\
\text { i Diff. }\end{array}$ & $\begin{array}{r}520 \pm 74 \\
461 \pm 97 \\
59 \pm 69\end{array}$ & $\begin{array}{c}490 \pm 81 \\
429 \pm 126 \\
61 \pm 80\end{array}$ & $\begin{array}{r}494 \pm 76 \\
439 \pm 99 \\
54 \pm 72\end{array}$ & $\begin{array}{r}539 \pm 66 \\
480 \pm 93 \\
58 \pm 70\end{array}$ \\
\hline $\begin{array}{l}\text { M.E.F. } \\
50 \% \\
(1 . / \text { sec. })\end{array}$ & $\begin{array}{l}1963 \\
1967 \\
\text { Diff. }\end{array}$ & $\begin{array}{l}4.35 \pm 1.24 \\
3.82 \pm 1.37 \\
0.53 \pm 1.04\end{array}$ & $\begin{array}{l}3.92 \pm 1.22 \\
3.33 \pm 1.35 \\
0.59 \pm 1.40\end{array}$ & $\begin{array}{l}4.07 \pm 1.28 \\
3.51 \pm 1.32 \\
0.56 \pm 0.95\end{array}$ & $\begin{array}{l}4.54 \pm 1.20 \\
4 \cdot 04 \pm 1.35 \\
0.50 \pm 1.09\end{array}$ \\
\hline $\begin{array}{l}\text { M.E.F. } \\
25 \% 0 \\
\text { (1./sec.) }\end{array}$ & $\mid \begin{array}{l}1963 \\
1967 \\
\text { inff. }\end{array}$ & $\begin{array}{l}1.56 \pm 0.56 \\
1.18 \pm 0.51 \\
0.38 \pm 0.44\end{array}$ & $\begin{array}{l}1.23 \pm 0.24 \\
0.93 \pm 00.41 \\
0.30 \pm 0.27\end{array}$ & $\begin{array}{l}1.44 \pm 0.56 \\
1.11 \pm 0.52 \\
0.33 \pm 0.48\end{array}$ & $\begin{array}{l}1.66 \pm 0.56 \\
1.26 \pm 0.50 \\
0.40 \pm 0.46\end{array}$ \\
\hline
\end{tabular}

There were no significant differences between decreases from 1963 to 1967 .

In Table II the results in groups with different smoking habits are compared. Twenty per cent. of the smokers smoked a pipe or cigars. The values for V.C., F.E.V., and M.E.F. $50 \%$ dropped more for the smokers than for both the nonsmokers and the ex-smokers. The non-smokers did not differ significantly from the ex-smokers in this respect, nor did the two groups of smokers differ from each other. More significant differences emerged between the various groups when the calculations were made by means of the percentage drop rather than the absolute change. Thus the V.C. dropped by 0.251 . between 1963 and 1967 in the non-smokers and by $0.38 \mathrm{l}$. in the subjects smoking more than $15 \mathrm{~g}$./day. While these absolutc values do not differ significantly, the relative drop was significantly higher for the smokers, who had a lower V.C. (4.56 1.) in 1963 than the non-smokers $(4.83$ 1.). The same was true of F.E.V. ${ }_{1}$ for the men who smoked more than $15 \mathrm{~g}$./day compared with the non-smokers and ex-smokers. As regards the M.E.F. $50 \%$, the two groups of smokers showed a significantly larger drop than the others when relative values were compared.

Fifteen of the men had given up smoking between 1963 and 1967 - seven in 1963, one in 1964, one in 1965, four in 1966, and two in 1967. Nine smoked 1-14 g./day and six more than $15 \mathrm{~g}$./day. One had chronic bronchitis and six had other respiratory symptoms. V.C., F.E.V., and P.E.F. dropped about the same amount in them as in the non-smokers and ex-smokers. No significant differences in decrease of ventilatory capacity were, however, found between them and the men who still smoked.

The distribution of respiratory symptoms among groups with various smoking habits are shown in Table III. Of the non-

TABLE III.-Respiratory Symptoms in Relation to Smoking Habits

\begin{tabular}{|c|c|c|c|c|c|c|c|c|}
\hline & \multicolumn{2}{|c|}{$\begin{array}{c}\text { Chronic } \\
\text { Bronchitis }\end{array}$} & \multicolumn{2}{|c|}{$\begin{array}{l}\text { With Other } \\
\text { Respiratory } \\
\text { Symptoms }\end{array}$} & \multicolumn{2}{|c|}{$\begin{array}{l}\text { Without } \\
\text { Respiratory } \\
\text { Symptoms }\end{array}$} & \multicolumn{2}{|c|}{ Total } \\
\hline & $\mathrm{n}$ & $\%$ & $\mathrm{n}$ & $\%$ & $\mathrm{n}$ & $\%$ & $\mathrm{n}$ & $\%$ \\
\hline 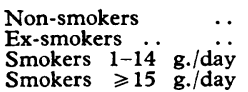 & $\begin{array}{r}1 \\
2 \\
5 \\
11\end{array}$ & $\begin{array}{r}1 \\
3 \\
5 \\
17\end{array}$ & $\begin{array}{l}23 \\
18 \\
34 \\
39\end{array}$ & $\begin{array}{l}26 \\
27 \\
36 \\
61\end{array}$ & $\begin{array}{l}64 \\
47 \\
55 \\
14\end{array}$ & $\begin{array}{l}73 \\
70 \\
59 \\
22\end{array}$ & $\begin{array}{l}88 \\
67 \\
94 \\
64\end{array}$ & $\begin{array}{l}100 \\
100 \\
100 \\
100\end{array}$ \\
\hline Total & 19 & 6 & 114 & 36 & 180 & 58 & 313 & 100 \\
\hline
\end{tabular}

smokers and ex-smokers 1 and $3 \%$, respectively, had chronic bronchitis, against 5 and $17 \%$ among the two groups of smokers. The prevalence of other respiratory symptoms was $26,27,36$, and $61 \%$, respectively. The prevalence of chronic bronchitis in this sample was $6.1 \%$ and in the total random sample (855 persons) $7 \cdot 6 \%$.

In groups with consistent smoking habits, those with respiratory symptoms generally had lower value for ventilatory capacity both in 1963 and in 1967 (Table IV). The decreases between 1963 and 1967 were, however, not significantly different between these groups. Moreover, in groups without respiratory symptoms increasing tobacco consumption caused decreasing ventilatory capacity. In groups with respiratory symptoms,

TABLE II.-Ventilatory Capacity in Series Divided by Smoking Habits in 1963. Those who Stopped Smoking Between 1963 and 1967 (9 from Group 3 and 6 from Group 4) are Collected in Group 5. Means and Standard Deviations.

\begin{tabular}{|c|c|c|c|c|c|c|c|c|}
\hline & & \multirow{2}{*}{$\begin{array}{l}\text { 1. Non-smokers } \\
(\mathrm{n}=88)\end{array}$} & \multirow{2}{*}{$\begin{array}{l}\text { 2. Ex-smokers } \\
(\mathrm{n}=67)\end{array}$} & \multirow{2}{*}{$\begin{array}{l}\text { 3. Smokers } \\
\text { 1-14 g./day } \\
(\mathrm{n}=94)\end{array}$} & \multirow{2}{*}{$\begin{array}{l}\text { 4. Smokers } \\
\begin{array}{l}\geqslant 15 \mathrm{~g} . / \mathrm{day} \\
(\mathrm{n}=64)\end{array}\end{array}$} & \multirow{2}{*}{$\begin{array}{l}\text { 5. Stopped } \\
\text { Smoking between } \\
1963 \text { and } 1967 \\
(\mathrm{n}=15)\end{array}$} & \multicolumn{2}{|c|}{$\begin{array}{l}\text { Significant Differences between } \\
\text { Decreases from } 1963 \text { to } 1967\end{array}$} \\
\hline & & & & & & & Absolute & $\%$ \\
\hline V.C. & $\left|\begin{array}{ll}1963 & \cdots \\
1967 & \cdots \\
\text { Diff. } & \cdots\end{array}\right|$ & $\begin{array}{l}4.83 \pm 0.83 \\
4.58 \pm 0.85 \\
0.25 \pm 0.46\end{array}$ & $\begin{array}{l}4 \cdot 77 \pm 0.76 \\
4 \cdot 46 \pm 0 \cdot 79 \\
0.23 \pm 0.30\end{array}$ & $\begin{array}{l}4 \cdot 83 \pm 0 \cdot 60 \\
4 \cdot 46 \pm 0 \cdot 66 \\
0 \cdot 37 \pm 0 \cdot 40\end{array}$ & $\begin{array}{l}4 \cdot 56 \pm 0.64 \\
4 \cdot 18 \pm 0 \cdot 59 \\
0 \cdot 38 \pm 0 \cdot 41\end{array}$ & $\begin{array}{l}4.71 \pm 0.91 \\
4.48 \pm 0.25 \\
0.23 \pm 0.39\end{array}$ & $\begin{array}{l}2-3 \mathrm{P}<0.02 \\
2-4 \mathrm{P}<0.02\end{array}$ & $\begin{array}{l}1-4 \mathrm{P}<0.05 \\
2-3 \mathrm{P}<0.02 \\
2-4 \mathrm{P}<0.02\end{array}$ \\
\hline \multirow{2}{*}{$\underset{(1 .)}{\text { F.E.V.1 }}$} & $1963 \ldots$ & $3 \cdot 77 \pm 0.67$ & $3 \cdot 69 \pm 0 \cdot 60$ & $3 \cdot 62 \pm 0 \cdot 47$ & $3 \cdot 39 \pm 0.53$ & $3 \cdot 60 \pm 0.62$ & $1-3 P<0.05$ & \multirow{2}{*}{$\begin{array}{l}1-3 P<0.05 \\
1-4 P<0.05 \\
2-3 P<0.05 \\
2-4 P<0.05\end{array}$} \\
\hline & I $1967 \cdots$ & $\begin{array}{l}3.60 \pm 0.62 \\
0.17 \pm 0.36\end{array}$ & $\begin{array}{l}3.55 \pm 0.63 \\
0.13 \pm 0.49\end{array}$ & $\begin{array}{l}3 \cdot 34 \pm 0 \cdot 43 \\
0 \cdot 28 \pm 0 \cdot 31\end{array}$ & $\begin{array}{l}3 \cdot 11 \pm 0 \cdot 48 \\
0 \cdot 28 \pm 0 \cdot 37\end{array}$ & $\begin{array}{l}3 \cdot 44 \pm 0 \cdot 63 \\
0 \cdot 16 \pm 0 \cdot 26\end{array}$ & $2-3 P<0.02$ & \\
\hline $\begin{array}{l}\text { P.E.F. } \\
\text { (1./min.) }\end{array}$ & $\begin{array}{l}1963 \ldots \\
\text { '1967 } \\
\text { 'Diff. } \cdots\end{array}$ & $\begin{array}{r}525 \pm 67 \\
474 \pm 98 \\
51 \pm 76\end{array}$ & $\begin{array}{c}539 \pm 78 \\
483 \pm 122 \\
56 \pm 84\end{array}$ & $\begin{array}{r}521 \pm 71 \\
463 \pm 90 \\
58 \pm 68\end{array}$ & $\begin{array}{r}492 \pm 77 \\
424 \pm 86 \\
68 \pm 58\end{array}$ & $\begin{array}{r}513 \pm 61 \\
474 \pm 68 \\
40 \pm 72\end{array}$ & - & - \\
\hline \multirow{3}{*}{$\begin{array}{l}\text { M.E.F. } \\
50^{\circ} \\
\text { (1./sec.) }\end{array}$} & $(1963 \ldots)$ & $4 \cdot 61 \pm 1 \cdot 17$ & $4 \cdot 39 \pm 1 \cdot 19$ & $4 \cdot 38 \pm 1 \cdot 23$ & $3 \cdot 87 \pm 1 \cdot 25$ & $4 \cdot 52 \pm 1 \cdot 17$ & \multirow{3}{*}{$\begin{array}{l}1-3 P<0.005 \\
1-4 P<0.02 \\
2-3 P<0.02\end{array}$} & \multirow{4}{*}{$\begin{array}{c}1-3 \mathrm{P}<0.001 \\
1-4 \mathrm{P}<0.001 \\
2-3 \mathrm{P}<0.001 \\
2-4 \mathrm{P}<0.005 \\
.\end{array}$} \\
\hline & $-1967 \ldots$ & $4 \cdot 39 \pm 1 \cdot 33$ & $4.05 \pm 1.44$ & $3 \cdot 62 \pm 1 \cdot 27$ & $3 \cdot 21 \pm 1 \cdot 23$ & $3 \cdot 78 \pm 1 \cdot 02$ & & \\
\hline & Diff. .. & $0 \cdot 22 \pm 1 \cdot 14$ & $0 \cdot 34 \pm 1 \cdot 14$ & $0 \cdot 76 \pm 1 \cdot 07$ & $0.66 \pm 0.89$ & $0.74 \pm 0.91$ & & \\
\hline $\begin{array}{l}\text { M.E.F. } \\
25 \% \\
(1 . / \mathrm{sec} .)\end{array}$ & $\begin{cases}1963 & \cdots \\
1967 & \cdots \\
\text { Diff. } & \cdots\end{cases}$ & $\begin{array}{l}1.75 \pm 0.60 \\
1.39 \pm 0.57 \\
0.36 \pm 0.56\end{array}$ & $\begin{array}{l}1.66 \pm 0.55 \\
1.21 \pm 0.47 \\
0.45 \pm 0.41\end{array}$ & $\begin{array}{l}1.50 \pm 0.53 \\
1 \cdot 10 \pm 0 \cdot 50 \\
0.40 \pm 0.46\end{array}$ & $\begin{array}{l}1.28 \pm 0.44 \\
0.98 \pm 0.43 \\
0.30 \pm 0.35\end{array}$ & $\begin{array}{l}1.64 \pm 0.68 \\
1 \cdot 19 \pm 0.40 \\
0.45 \pm 0.57\end{array}$ & $2-4 P<0.05$ & \\
\hline
\end{tabular}


however, the influence of tobacco smoking was not so evident. The absolute decrease of ventilatory capacity between 1963 and 1967 was not significant between any of the groups, partly because of a small number of subjects without symptoms in the group of smokers of more than $15 \mathrm{~g}$./day. Statistically significant differences between two groups, however, were found when the percentage decreases were compared (Table IV).

\section{Discussion}

The results of various authors making horizontal studies and using linear regression analysis of the reduction in ventilatory capacity with increasing age are shown in Tables V and VI. These authors examined persons who had no respiratory symptoms, but most of their series included smokers and nonsmokers. Both smokers and non-smokers were studied in the last series described by one of us (Wilhelmsen, 1968) (Tables $\mathrm{V}$ and VI). This series was selected on the basis of the same questionary as in the present study, the subjects thus corresponding to group 2 in our Table IV. The different authors found from their regression equations that V.C. decreased between 0.09 and 0.041 ./year, as compared with 0.081 . in the present group who had no respiratory symptoms. Their figures for the annual decrease in F.E.V. ${ }_{1}$ ranged from 0.02 to 0.041 , as compared with nearly 0.061. year in the present group. In the papers by Cotes et al. (1966) and Wilhelmsen (1968) sufficient. data were given to allow a statistical comparison; the present values were highly significantly different from those mentioned.

To discover the reason for these differences in decrease of F.E.V., , especially between the present results and those obtained in the other study (Wilhelmsen, 1968), we first examined the method we used. As already mentioned, the same apparatus was used in both studies, the same persons undertook the examinations, the same instructions were given, and, so far as could be judged, the persons were studied under the same conditions-including the same time of year. The ServoSpirometer was checked in the same way before and after the series of measurements in 1963 and 1967. The volume and flow data given by the apparatus were checked every day without any variations being noted in the results. Nor did checking the Wright peak-flow meter point to any fault in the apparatus. The measurements were made at different times of day. The subjects had been fasting on both occasions. Carey et al. (1967, 1968) found a decline of F.E.V., during the day of 0.0431 . in non-smokers and $0.071 \mathrm{l}$. in smokers; but even if those high daily declines of F.E.V., were calculated in this series the yearly decline is significantly greater than predicted according to the above-mentioned equations.

In an earlier study (Wilhelmsen, 1968) of the same men without respiratory symptoms at the age of 50 , the values for
V.C., F.E.V., M.E.F. $50 \%$, and M.E.F. $25 \%$ corresponded well with the means calculated from the regression equations. Thus after this age the ventilatory capacity seems to drop at a faster rate than that calculated from available regression equations. In a study of men aged 25-34 and 55-64 from an industrial town, some of them miners, Higgins et al. (1968) found that F.E.V. ${ }_{0.7 .}$ dropped an average of 0.021 ./year in non-smokers in the young age group against 0.031 . in the older non-smokers. In the young group F.E.V. $\cdot_{0.75}$ dropped each year by $0.6 \%$ of the mean F.E.V. 0.75 during the nine years, as compared with $1.3 \%$ for the older men. The corresponding drop in F.E.V., in the present series amounted to $1 \%$, which, when the difference in age is considered, corresponds well with the observations of Higgins et al. Fletcher (1968) found that F.E.V., fell an average of 0.0261 ./year in 904 men followed for four to five years. This is significantly less than that noted here and less than that found by Higgins et al.

TABLE V.-Regression Equations for Height (cm.) and Age (Years) on V.C. (l.) or F.V.C. (l.) in Men According to Various Authors

\begin{tabular}{|c|c|c|c|c|c|}
\hline & v.c. & F.V.C. & Height & Age & R.S.D. \\
\hline $\begin{array}{lll}\text { Berglund } \text { et al. (1963) } & \ldots & \ldots \\
\text { Ferris } \text { et al. (1965) } & \ldots & \ldots \\
\text { Goldman and Becklake (1959) } & \ldots \\
\text { Kory } \text { et al. (1961) } & \ldots & \ldots \\
\text { Needham } \text { et al. (1954) } & \ldots \\
\text { Pemberton and Flanagan (1956) } \\
\text { Wilhelmsen (1968) }\end{array}$ & $\begin{array}{l}0.053 \\
0.064 \\
0.052 \\
0.048 \\
0.067\end{array}$ & 0.051 & $\begin{array}{l}0.022 \\
0.025 \\
0.031 \\
0.022 \\
0.039 \\
0.029 \\
0.017\end{array}$ & $\begin{array}{l}3 \cdot 09 \\
3 \cdot 55 \\
5 \cdot 34 \\
3 \cdot 60 \\
2 \cdot 12 \\
2 \cdot 42 \\
5 \cdot 78\end{array}$ & $\begin{array}{l}0.55 \\
0.59 \\
0.49 \\
0.58 \\
0.44 \\
0.59\end{array}$ \\
\hline
\end{tabular}

R.S.D. $=$ Residual standard deviation.

TABLE VI.-Regression Equations for Height (cm.) and Age (Years) on F.E.V.1 (l.) in Men According to Various Authors

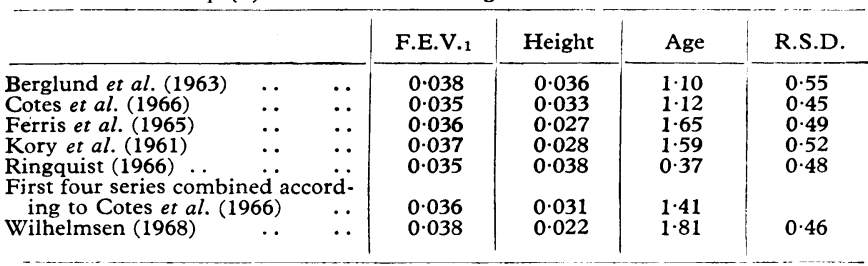

The present results indicate that the ventilatory capacity may not decrease linearly after the age of 20 , as is generally assumed in calculating with regression equations. The increasing air pollution during recent years may have accelerated the reduction in ventilatory capacity with age compared with that found earlier. Another explanation may be that the older subjects without respiratory symptoms, used for regression analysis, constitute a group of more positively selected people. The respiratory symptoms-for instance, dyspnoea-are commoner at higher ages, and therefore a smaller part of the population will be accepted as " normals."

In the present study the number of respiratory symptoms did not affect the rate of the drop in ventilatory capacity with

TABle IV.-Ventilatory Capacity in Series Divided by Smoking Habits and Respiratory Symptoms. Means and Standard Deviations

\begin{tabular}{|c|c|c|c|c|c|c|c|c|c|}
\hline & & \multicolumn{2}{|c|}{ Non-smokers } & \multicolumn{2}{|c|}{ Smokers $1-14 \mathrm{~g} . /$ day } & \multicolumn{2}{|c|}{ Smokers $\geqslant 15 \mathrm{~g} . /$ day } & \multirow{2}{*}{\multicolumn{2}{|c|}{$\begin{array}{l}\text { Significant Differences between } \\
\text { Decreases from } 1963 \text { to } 1967\end{array}$}} \\
\hline & & \multirow{2}{*}{$\begin{array}{l}\text { 1. Without } \\
\text { Respiratory } \\
\text { Symptoms } \\
(\mathrm{n}=64)\end{array}$} & \multirow{2}{*}{$\begin{array}{c}2 . \text { With } \\
\text { Respiratory } \\
\text { Symptoms } \\
(\mathrm{n}=24)\end{array}$} & \multirow{2}{*}{$\begin{array}{l}\text { 3. Without } \\
\text { Respiratory } \\
\text { Symptoms } \\
(\mathrm{n}=55)\end{array}$} & \multirow{2}{*}{$\begin{array}{l}\text { 4. With } \\
\text { Respiratory } \\
\text { Symptoms } \\
(n=39)\end{array}$} & \multirow{2}{*}{$\begin{array}{l}\text { 5. Without } \\
\text { Respiratory } \\
\text { Symptoms } \\
(n=14)\end{array}$} & \multirow{2}{*}{$\begin{array}{l}\text { 6. With } \\
\text { Respiratory } \\
\text { Symptoms } \\
(\mathrm{n}=78)\end{array}$} & & \\
\hline & & & & & & & & Absolute & $\%$ \\
\hline$\underset{\text { (1.) }}{\text { F.E.V.1 }}$ & $\left\{\begin{array}{l}1963 \ldots \\
1967 . . \\
\text { iDiff. } . .\end{array}\right.$ & $\begin{array}{l}3.94 \pm 0.56 \\
3.70 \pm 0.51 \\
0.23 \pm 0.31\end{array}$ & $\begin{array}{l}3.45 \pm 0.74 \\
3.31 \pm 0.75 \\
0.14 \pm 0.41\end{array}$ & $\begin{array}{l}3.70 \pm 0.51 \\
3.43 \pm 0.45 \\
0.28 \pm 0.34\end{array}$ & $\begin{array}{l}3.45 \pm 0.59 \\
3.21 \pm 0.61 \\
0.25 \pm 0.25\end{array}$ & $\begin{array}{l}3.57 \pm 0.71 \\
3.13 \pm 0.68 \\
0.45 \pm 0.40\end{array}$ & $\begin{array}{l}3.37 \pm 0.50 \\
3.15 \pm 0.53 \\
0.22 \pm 0.32\end{array}$ & - & $1-5 P<0.05$ \\
\hline $\begin{array}{l}\text { M.E.F.F. } \\
50 \% \\
\text { (1./sec.) }\end{array}$ & $\left\{\begin{array}{l}1963 \ldots \\
1967 \ldots \\
\text { Diff. }\end{array}\right.$ & $\begin{array}{l}4.83 \pm 1.06 \\
4.50 \pm 1 \cdot 26 \\
0.33 \pm 1 \cdot 14\end{array}$ & $\begin{array}{l}4 \cdot 38 \pm 1 \cdot 11 \\
4 \cdot 08 \pm 1 \cdot 42 \\
0 \cdot 30 \pm 0 \cdot 85\end{array}$ & $\begin{array}{l}4 \cdot 45 \pm 1.22 \\
3.78 \pm 1.28 \\
0 \cdot 66 \pm 0.96\end{array}$ & $\begin{array}{l}4 \cdot 24 \pm 1 \cdot 24 \\
3 \cdot 29 \pm 1 \cdot 10 \\
0.95 \pm 1 \cdot 11\end{array}$ & $\begin{array}{l}3.93 \pm 1.42 \\
3.28 \pm 1.40 \\
0.65 \pm 0.91\end{array}$ & $\begin{array}{l}3.84 \pm 1.33 \\
3.31 \pm 1.23 \\
0.54 \pm 0.96\end{array}$ & - & $1-3 P<0.05$ \\
\hline $\begin{array}{l}\text { M.E.F. } \\
25 \% \\
(1 . / \text { sec.) }\end{array}$ & $\begin{cases}1963 & \ldots \\
1967 & \cdots \\
\text { Diff. } & \cdots\end{cases}$ & $\begin{array}{l}1.85 \pm 0.53 \\
1.45 \pm 0.53 \\
0.40 \pm 0.44\end{array}$ & $\begin{array}{l}1.61 \pm 0.67 \\
1.25 \pm 0.63 \\
0.37 \pm 0.69\end{array}$ & $\begin{array}{l}1.59 \pm 0.57 \\
1 \cdot 17 \pm 0.49 \\
0.42 \pm 0.45\end{array}$ & $\begin{array}{l}1.39 \pm 0.44 \\
1.06 \pm 0.49 \\
0.33 \pm 0.46\end{array}$ & $\begin{array}{l}1.23 \pm 0.43 \\
1.04 \pm 0.51 \\
0.20 \pm 0.41\end{array}$ & $\begin{array}{l}1.29 \pm 0.48 \\
1.01 \pm 0.44 \\
0.28 \pm 0.31\end{array}$ & - & - \\
\hline
\end{tabular}


age. The initial values were, however, lower in those people with symptoms. Our findings agree on the whole with Fletcher's cbscrvations that an upper respiratory infection never caused a particularly rapid fall in F.E.V. A few of our patients with respiratory symptoms, however, showed a much greater drop in ventilatory capacity than the average subject, and a greater drop than any subject without any respiratory symptoms.

Our study thus confirms the observations of Fletcher and of Higgins et al. that cigarette smoking has a definite effect in decreasing the ventilatory capacity. Thus in Higgins $c t$ al.'s 25-34 age group the non-smokers showed a drop in F.E.V. $\cdot_{0.75}$ of 0.0211 . year, as opposed to a drop of 0.0371 . for the subjects smoking 1-14 g./day, $0.038 \mathrm{l}$. for the subjects smoking more than $15 \mathrm{~g}$./day, and 0.0291 . for the ex-smokers. The corresponding figures for their 55-64 age group were 0.032, 0.044, 0054 , and 0.037 1. Fletcher found a correlation between cigarette smoking and sputum eosinophilia, on the one hand, and an accelerated drop in F.E.V. on the other ; this was interpreted as increased bronchial "sensitivity" in some cigarette smokers. Thus smoking seems to worsen the pulmonary function whether or not the subject has respiratory symptoms. For example, Wilhelmsen and Tibblin (1966) found a significantly lower ventilatory capacity in heavy smokers having no respiratory symptoms than in non-smokers. The present study also points to a more rapid drop in ventilatory capacity among heavy smokers without chronic bronchitis than among nonsmokers and ex-smokers.

Hence these findings suggest that, in choosing control subjects, not only the absence of respiratory symptoms but also the smoking habits have to be considered. The cessation of smoking could not be shown to diminish ventilatory capacity significantly less than in those who still smoked, though there was a tendency in this direction. An improved ventilatory function after varying periods of non-smoking has been demonstrated by Krumholz et al. (1965), Wilhelmsen (1967), and Peterson et al. (1968).

\section{REFERENCES}

Berglund, E., et al. (1963). Acta Medica Scandinavica, 173, 185.

Carey, G. C. R Dawson, T. A. J., and Merritt, J. D. (1967). British Fournal of Prcventive and Social Medicine, 21, 86.

Carey, G. C. R., Dawson, T. A. J., and Merrett, J. D. (1968). British Fournal of Preventive and Social Medicine, 22, 59.

Cotes, J. E., Rossiter, C. E., Higgins, I. T. T., and Gilson, J. C. (1966). British Medical fournal, 1, 1016.

Ferris, B. G., jun., Andersson, D. O., and Zickmantel, R. (1965). American Review of Respiratory Diseases, 91, 252.

Fletcher, C. M. (1968). fournal of the Royal College of Physicians of London, 2, 183.

Goldman, H. I., and Becklake, M. R. (1959). American Rcviєw of Tuberculosis and Pulmonary Diseases, 79, 457.

H:ggins, I. T. T., Gilson, J. C., Ferris, B. G., jun., Waters, M. E., Campbell, H., and Higgins, M. W. (1968). American fournal of Public Health, 58, 1667 .

Higgins, I. T. T., and Oldham, P. D. (1962). British fournal of Industrial Medicine, 19, 65.

Kory, R. C., Calahan, R., Boren, H. G., and Syner, J. C. (1961). American fournal of Medicine, 30, 243.

Krumholz, R. A., Chevalier, R. B., and Ross, J. C. (1965). Annals of Internal Medicine, 62, 197.

Medical Research Council's Committee on the Aetiology of Chronic Bronchitis (1965). Lancet, 1, 775.

Needham, C. D. Rogan, M. C., and McDonald, I. (1954). Thorax, 9, 313.

Pemberton, J., and Flanagan, E. G. (1956). Foumal of Applied Physio$\log y, 9,291$.

Peterson, D. I., Lonergan, L. H., and Hardinge, M. G. (1968). Archives of Environmental Health, 16, 215.

Ringqvist, T. (1966). Scandinavian fouinal of Clinical and Laboratory Investigation, Suppl. No. 88.

Welch, B. L. (1949. Biometrika, 36, 293.

Wilhelmsen, L. (1967). Scandinavian fournal of Respirato;y Discase, 48, 407.

Wilhelmsen, L. (1968). Acta Medica Scandinavica, Suppl. No. 489.

Wilhelmsen, L., and Tibblin, G. (1966). Scandinavian fournal of Respiratory Disease, 47, 121.

Respiratory Disease, 47, 121.
Wright, B. M., and McKerrow, C. B. (1959). British Medical fournal, 2, 1041 .

\title{
Exercise-induced Asthma
}

\author{
A. SEATON,* B.A., M.B., M.R.C.P. ; GLYN DAVIES, $\dagger$ B.SC., F.R.I.C. ; D. GAZIANO, $;$ M.D. \\ R. OSBORNE HUGHES, $\S$ M.B., B.SC., M.R.C.P.
}

British Medical fournal, 1969, 3, 556-558

Cummary : Tests in three patients with asthma occurring $S$ only on exertion showed t'cat F.E.V., fell progressively on exercise, to reach a minimum after 10 minutes. Al! patients showed a striking metabolic acidosis, with an accumulation of the products of anaerobic metabolism.

\section{Introduction}

It is well known that exercise may induce bronchoconstriction in asthmatic subjects (Jones et al., 1962), and in some patients wheezing on exertion is the sole manifestation of illness (McNeill ct al., 1966 ; Crompton, 1968 ; Rebuck and Read, 1968). There is some uncertainty about the manner in which exercise produces bronchoconstriction, and to investigate this problem we have studied three patients with exercise-induced asthma.

\section{Techniques}

The patients were all studied in the same manner. All gave informed consent for these procedures. A Teflon cannula was introduced percutaneously into the radial or brachial artery and the patient was allowed to rest for a few minutes. The vital capacity and forced expiratory volume in one second
(F.E.V.) was then estimated by a pulmometer (Godart) on three occasions and a control arterial blond sample was taken. This and all subsequent samples were analysed for $\mathrm{pH}, \mathrm{PCO}_{2}$, $\mathrm{Po}_{2}$, lactate, and pyruvate. $\mathrm{pH}$ was measured by a Radiometer capillary electrode, $\mathrm{PCO}_{2}$, with a Severinghaus electrode, and the Sigaard-Andersen nomogram was used for calculation of base excess and standard bicarbonate. Po., was measured with an EIL Bishop electrode. The arterial blood was analysed enzymatically for lactate and pyruvate (Bochringer kits) and excess lactate was calculated from Huckabee's (1958a) equation as $(\mathrm{Ln}-\mathrm{Lo})-(\mathrm{Pn}-\mathrm{Po})(\mathrm{Lo} / \mathrm{Po})$, where $\mathrm{Lo}$ and $\mathrm{Po}$ are initial and $\mathrm{Ln}$ and $\mathrm{Pn}$ subsequent concentrations of lactate and pyruvate respectively in millimoles per litre. The patient was then asked to hyperventilate until he felt tingling in his fingers. A second arterial sample was obtained and three further cstimations of F.E.V., were made. When his F.E.V., and blood gases had returned to normal the patient rebreathed $5 \%$ carbon dioxide in oxygen for five minutes and a further arterial sample and measurements of F.E.V., were obtained.

\footnotetext{
* Senior Medical Registrar.

+ Biochemist.

Rescarch Fcllow.

Regional Pulmonary Function Laboratory, Broadgrecn Hospital, Liverpool 14 .
}

$\S$ Medical Registrar, Royal Infirmary, Livirpool 3. 